\title{
年度，年齢，世代の効果を もつ線形模型
}

赤井豊秋, 淽谷政昭 慶応義熟大学理工学部

要 旨 いわゆるコホート模型の世代効果について同定・推定可能なのは その 2 次差分であり，標準㷌無仮説は 2 次差分がすべて零といら仮説であ る.世代効果そのものの推測の有効性は疑わしい. 肝硬変死亡率データ， 自殺死亡率データの解析の結果「昭和一桁生まれが特異である」といら主 㖘が再確認されるものの，別の見方が可能であることを指摘する．その一 つとして，非線形模型で，世代効果の“鍇視”を与える例を述べる，世代 効果の概念そのものの有效範囲は狭い。

Key words: cohort model, two-way factorial model, identifiability, estimability, epidemiolgy, sociology.

\section{1. いわゆるコホート模型}

日本全国のような二定地域の住民について, 標本調查により, 経年的に年龄 別に, 消費量のような経済・社会調查, 体力のような健康調查, なとを行い, 湘定值またはその变数変換を 2 元分類の線形模型

$$
y_{i j}=\alpha_{i}+\beta_{j}+(\alpha \beta)_{i j}+e_{i j} \quad i=1, \cdots, a ; j=1, \cdots, b ;
$$

により表わす。年度效果 $\alpha_{i}$ の水準が $\delta$ 年ごとの測定か $\delta$ 年間の測定を表わ

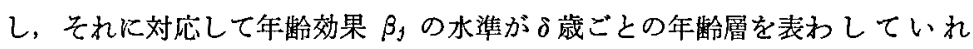
ば，同世代の人々が集団（コホート cohort）をなし，何回か継続して観测され ることになる，習慣に反して添字 $i$ を新しい年度から古い年度の順に動かすこ とにする. 添字 $j$ の方は若い方から年㱓の昇順につけると，添字の組

$$
\{(i, j) ; i+j-1=k\}, \quad k=1 ; \cdots, a+b-1
$$

が同世代を表わす， $i ， j ， k$ すべて，若い方（現在）を若い番号で表わすこ とになる（第 1 表を参照）。

Glenn[8]によると，専門用語としては“世代（generation)”を親子関保を 論ずる場合に限り，今の場合は“出生によるコホート”と呼ぶべきたとのこと 
第 1 表. 同世代についての測定, $\boldsymbol{i}+\boldsymbol{j}-\mathbf{1}=\boldsymbol{k}$.

\begin{tabular}{|c|c|c|c|c|c|}
\hline$i$ & J & $\begin{array}{c}\beta_{1} \\
40-44\end{array}$ & $\begin{array}{c}\beta_{2} \\
45-49\end{array}$ & $\begin{array}{c}\beta_{3} \\
50-54\end{array}$ & $\begin{array}{c}\beta_{4} \\
55-59\end{array}$ \\
\hline$\alpha_{i}$ & 1980. & $y_{11}$. & $y_{12}$ & $y_{12}$ & $y_{14}$ \\
\hline$\alpha_{2}$ & 1975 & $y_{21}$ & $y_{22}$ & $y_{23}$ & $y_{24}$ \\
\hline$\alpha_{3}$ & 1970 & $y_{31}$ & $y_{32}$ & $y_{33}$ & $y_{34}$ \\
\hline
\end{tabular}

である. しかしここでは，親子関係を離れた意味で日常用いられている世代のままとする.

社会学者や疫学者は，交互作用 $(\alpha \beta)_{1 j}$ がある年度のある年路によるものではなく，各世代に固有のものとみ なし（1）を変えた

$$
E\left[y_{i j}\right]=\alpha_{i}+\beta_{\jmath}+\gamma_{i+j-1}, \quad i=1, \cdots, a ; j=1, \cdots, b ;
$$

という線形構造を仮定する。あるいは，さらに一般平均項を加えた

$$
E\left[y_{i j}\right]=\mu+\alpha_{i}+\beta j+\gamma_{i+j-1}
$$

（添字の笨囲は同じ）をコホート模型（cohort model）と呼んでいる. 計数，此率なぞを含む一般の型のデータ

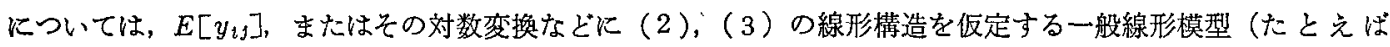
McCullagh and Nelder[11]) の枠組で論ずることになる. 模型（2），(3）の母数は冗長であり，同定可能 (identifiable) でないが，種々の前提条件を加えて $\gamma_{k}$ を推定し，推定值を解积しょうとする試みがなされてい る. たとえば，中村 [6]，丹後[5]，石井[2]，Holford[9] が最近の仕事である. コホート分析の簡単な解説， （3）の推定に打ける論争の紹介として Namboodiri[12] が役に立つ.

ここでは線形模型の势組（たとえば Rao[13]）で既知のことを平凡に適用して何が分かるかを議論する，その 限りでは線形代数の計算が主体で，一般線形模型でる，古典的な線形模型でも話は共通である.

\section{2. 模型の代数計算}

コホート模型（2）の行列, ベクトル表示を

$$
E[y]=X \theta
$$

とする. $X$ は $a b$ 行 $2(a+b)-1$ 列の行列である. $a=3, b=4$ の場合を陽に書くと，

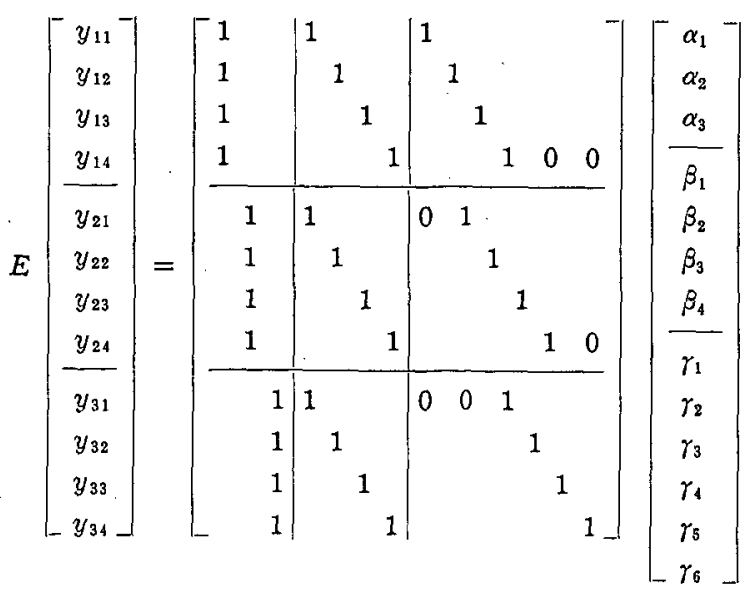


となる. 以下，陽に書きたいときは断りなく $a=3, b=4$ の場合に限ることにする. 模型（3）の行列は $X の$ 左に，全要素が1の $a b$ 次元べクトルを並べた $[1: X]$ である. 主としてXについて説明する. 命題1は既知 であるが, 後の議論のために 2 つ証明を述べておく。

\section{命題 1}

$$
\operatorname{rank} X=\operatorname{rank}[1: X]=2(a+b-2)
$$

\section{証明 1}

$X$ の列を（5）式の縦線のよらに $a$ 列， $b$ 列， $a+b-1$ 列に分割したものを $X=[U: V: W]$ とし，Vの最 後の 1 列を除いたものを $\tilde{V}, W$ 最後の 2 列を除いたるのを $\tilde{W}$ をる: $[U: \tilde{V}: \tilde{W}]$ の列ベクトルの組が線形 独立であり，その線形結合として除いた列を表現できることを確める，列の除き方は他にもいろいるある。

\section{証明 2}

行列 $X$ を $X=F_{1} F_{2}$ と階数分解できる. ただし $F_{1}$ は $a b$ 行 $2(a+b-2)$ 列, $F_{2}$ は $2(a+b-2)$ 行 $2(a+b)-1$ 列で, ともに階数 $2(a+b-2)$ の次の上らな行列である.

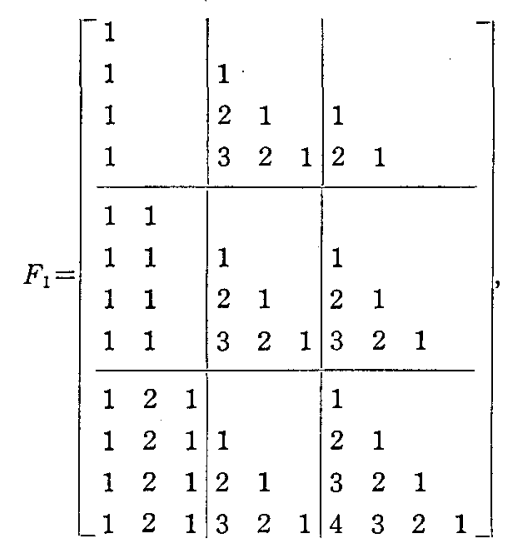

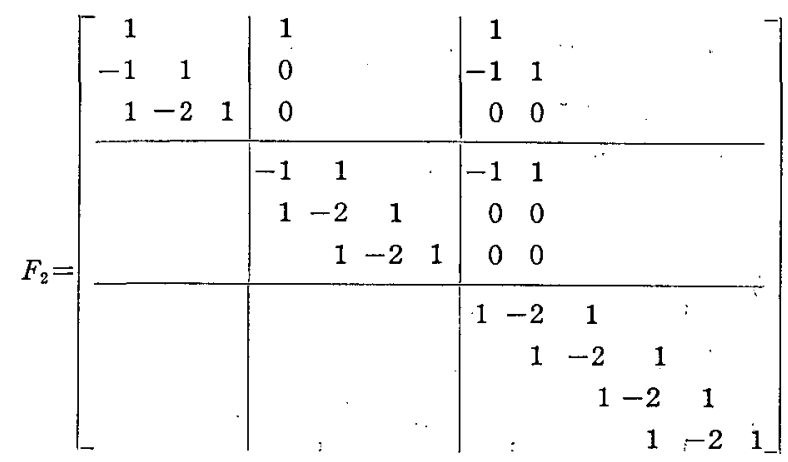

\section{命題 2}

$$
S:=\left[s_{1}: s_{2}: s_{3}\right]:=\left[\begin{array}{rrr}
1 & 0 & 0 \\
1 & 0 & 1 \\
1 & 0 & 2 \\
\hline 0 & 1 & 0 \\
0 & 1 & 1 \\
0 & 1 & 2 \\
0 & 1 & 3 \\
-1 & -1 & 0 \\
-1 & -1 & -1 \\
-1 & -1 & -2 \\
-1 & -1 & -3 \\
-1 & -1 & -4 \\
-1 & -1 & -5
\end{array} \mid \quad \begin{array}{l}
(2(a+b)-1 \text { 行 3 列. } \\
S \text { の横線は } a \text { 行, } b \text { 行 } \\
a+b-1 \text { 行への分割を } \\
\text { 示す. })
\end{array}\right.
$$

とするとSの值域空間 (列空間) $\mathscr{R}(S)$ は $X$ の零空間 $\mathscr{N}(X)$ に等しい.

\section{証明}

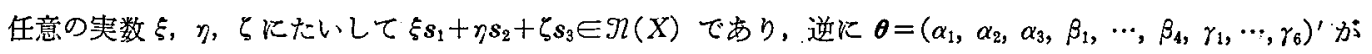

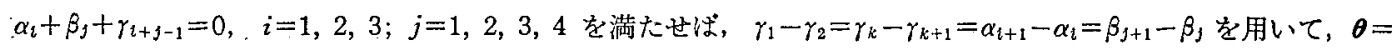


$\alpha_{1} s_{1}+\beta_{1} s_{2}+\left(\gamma_{1}-\gamma_{2}\right) s_{3}$ と表わせる.

注意 $S$ の代りに

$$
T:=\left[\boldsymbol{t}_{1}, \boldsymbol{t}_{2}, \boldsymbol{t}_{3}\right]:=\left[s_{1}-s_{2}, b s_{1}+a s_{2}, s_{3}-\frac{a-1}{2} s_{1}-\frac{b-1}{2} s_{2}\right]=\left[\begin{array}{rrr}
1 & 4 & -1 \\
1 & 4 & 0 \\
1 & 4 & 1 \\
\hline-1 & 3 & -1.5 \\
-1 & 3 & -0.5 \\
-1 & 3 & 0.5 \\
-1 & 3 & 1.5 \\
\hline 0 & -7 & 2.5 \\
0 & -7 & 1.5 \\
0 & -7 & 0.5 \\
0 & -7 & -0.5 \\
0 & -7 & -1.5 \\
0 & -7 & -2.5
\end{array}\right]
$$

を用いても $R(T)=\mathscr{N}(X)$ となり，この列は $\Re(X)$ の直交基底となっている. 任意の传数 $\theta^{*}=\left(\alpha_{1}{ }^{*}, \cdots, \beta_{1}{ }^{*}\right.$ ， $\left.\cdots, \gamma_{1}^{*}, \cdots\right)$ にたいして $\theta=\xi s_{1}+\eta s_{2}+\zeta s_{3}$ または $\theta=\xi t_{1}+\eta t_{2}+\zeta t_{3}(\xi, \eta ， \zeta$ は自由パラメータ）とすれば $X \theta=$ $X \theta^{*}$ の意味で模型は不変である.

命題 3

(a) $\sum_{i=1}^{a} \alpha_{i}=\sum_{j=1}^{b} \beta_{j}=\sum_{k=1}^{a+b-1} r_{k}$

打よび, 3 条件

(b) $\sum_{i=1}^{a}(i-1) \alpha_{i}+\sum_{j=1}^{b}(j-1) \beta_{j}-\sum_{k=1}^{a+b-1}(k-1) \gamma_{k}=0$

(b') $\sum_{i=1}^{a} i \alpha_{i}+\sum_{j=1}^{b} j \beta_{j}-\sum_{k=1}^{a+b-1}(k+1) \gamma_{k}=0$

(b") $\sum_{i=1}^{a}\left(i-\frac{a+1}{2}\right) \alpha_{i}+\sum_{j=1}^{b}\left(j-\frac{b+1}{2}\right) \beta_{j}-\sum_{k=1}^{a+b-1}\left(k-\frac{a+b}{2}\right) \gamma_{k}=0$

の任意の 1 つの下で (2) の最小 2 乗解は一意に定まる。

証明

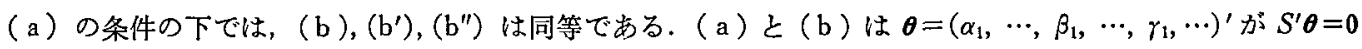
を満たす，つまり $\theta \in \mathscr{R}\left(X^{\prime}\right)$ の必要十分条件である.

模型（3）では計算がさらに複雑となる。命題 3 に対応するものの結果たけを述べて括く.

\section{命題 4}

(a') $\sum_{i=1}^{a} \alpha_{i}=\sum_{j=1}^{b} \beta_{j}=\sum_{k=1}^{a+b-1} \gamma_{k}=0$

打よび命題 3 の条件 (b) または $\left(b^{\prime}\right)$ または $\left(b^{\prime \prime}\right)$ の下で（ 3 ）の最小 2 乗解は一意に定まる.

証明は省略する．第 5 節を参照せよ。

多くの線形模型では，パラメータを圥長にし，これに対称な制約条件を加えることにより，最小 2 乗解ないし 最尤解を陽に表わすことができる. 推定値の解釉で人が誤まる危険があってす利用される理由の一つである. 模 型（2）（3）でその上らな可能性がないかと考㝋て得られた制約条件が命題 3 の結果である. しかしこれらを 用いても陽な表現は得られなかった。このことは逆に，(2)，（3）の冗長な表現にこだわる意味がないことを意 味する. むしろ命題 1 の証明 1 に従ってて長を除けば, 正規方程式を作らずに直交変換による計算法（たとえば 
Longley [10]) も利用できる.

\section{3. 世代効果について可能な推測}

どのような母数関数が同定・推定可能かを見るのに命題 1 の証明 2 の結果を用いると，

$$
\begin{aligned}
& X \boldsymbol{\theta}=F_{1} F_{2} \theta \\
& F_{2} \theta=\left(\alpha_{1}+\beta_{1}+\gamma_{1}, \Delta \alpha_{1}+\Delta \gamma_{1}, \Delta^{2} \alpha_{1}, \cdots, \Delta \beta_{1}+\Delta \gamma_{1}, \Delta^{2} \beta_{1}, \cdots, \Delta^{2} \gamma_{1}, \cdots\right)
\end{aligned}
$$

である. 線形推定可能なのは

$$
\begin{aligned}
& \alpha_{i}+\beta_{j}+\gamma_{i+j-1}, \quad \alpha_{i}-\alpha_{j}+\gamma_{t+k}-\gamma_{j+k}, \quad \beta_{i}-\beta_{j}+\gamma_{i+k}-\gamma_{j+k}, \quad\left(\alpha_{i}-\alpha_{j}\right)-\left(\beta_{l}-\beta_{j}\right), \\
& \left(\alpha_{i}-\alpha_{t+k}\right)-\left(\alpha_{j}-\alpha_{j+k}\right),\left(\beta_{i}-\beta_{i+k}\right)-\left(\beta_{j}-\beta_{j+k}\right), \quad\left(\gamma_{i}-\gamma_{t+k}\right)-\left(\gamma_{j}-\gamma_{j+k}\right), \Delta^{2} \alpha_{t}, \\
& \Delta^{2} \beta_{j}, \Delta^{2} \gamma_{k}
\end{aligned}
$$

などであり

$$
\alpha_{l}, \beta_{1}, \gamma_{k}, \alpha_{\imath}-\alpha_{\jmath}, \beta_{l}-\beta_{1}, \gamma_{l}-\gamma_{k}, \Delta \alpha_{l}, \Delta \beta_{1}, \Delta \gamma_{k}
$$

などは線形推定可能ではない，2階差分の累和により，たと学ば

$$
\Delta \gamma_{2}-\Delta \gamma_{1}, \Delta \gamma_{3}-\Delta \gamma_{1}, \Delta \gamma_{4}-\Delta \gamma_{1}, \cdots
$$

が推定できる.つまり不定定数を除いて 1 階差分の列が推定できる.

(2)，（3）の模型で世代効果の検定を行うことができる．後述のょう火，意味のあるのは

\begin{tabular}{|c|c|c|c|c|}
\hline 要 & 因 & 平方 & 和 & 度 \\
\hline 年 & 度 & \multirow{2}{*}{\multicolumn{2}{|c|}{$\begin{array}{l}S_{\alpha} \\
S_{\beta} \\
\end{array}$}} & \multirow{2}{*}{$a-1$} \\
\hline 年 & 龉 & & & \\
\hline $\begin{array}{l}\text { 世 } \\
\text { 誤 }\end{array}$ & $\begin{array}{l}\text { 代 } \\
\text { 差 }\end{array}$ & \multicolumn{2}{|c|}{$\left.\begin{array}{l}S_{\tau} \\
S_{e}\end{array}\right\} S_{e}^{\prime}$} & $\left.\begin{array}{l}a+b-3 \\
(a-2)(b-2)\end{array}\right\}(a-1)(b-1)$ \\
\hline & & $S_{T}$ & & $a b-1$ \\
\hline
\end{tabular}

$$
H_{\gamma}: \quad \Delta^{2} \gamma_{1}=\cdots=\Delta^{2} \gamma_{a+b-3}=0
$$

という仮説である.つまり（6）式 $F_{2} \theta$ の末尾のパラメータを0とする仮説である.

正挸誤差の条件の下での分散分析表は第 2 表のようになる. 反復のない 2 元分類の通常の分散分析により $S_{\alpha}$, $S_{\beta}, S_{\tau}+S_{e}$ が求まり（2）の模型の最小 2 乗解より $S_{\alpha}+S_{\beta}+S_{\tau}, S_{e}$ が求まる. 一般のデータの型の場合に は， $H_{r}$ を最大尤度比で検定することになる。

第 2 表. 模型（2）の分散分析表

$H_{r}$ は交互作用に関する諸検定（たとえば広津[7]，ラォ[12]参照）のひとつとみなすこともできる.Tukey 検 定などより強力な場合も多いであらう.ただし一般の 2 元分類では, 第 1 婊のように左下から右上に一様とする 対立仮説だけでなく，逆に左上から右下に一様とする対立仮説も可能である.

第 2 節で述べたように $\theta=\theta^{*}+\xi t_{1}+\eta t_{2}+\zeta t_{3}$ と母数を变えても模型は不変である. $\theta$ の $\gamma_{k}$ の成分について は，特定の $\gamma_{k}^{*}$ を

$$
\gamma_{k}=\gamma_{k}^{*}-(a+b) \eta-\left(k-\frac{a+b}{2}\right) \zeta
$$

と変えられることになる。つまり，

$$
\begin{aligned}
r_{1}^{*}=\cdots & =r_{a+b-1}^{*}=0 \\
& -5-
\end{aligned}
$$


と “ $\gamma_{k} か ゙ k の 1$ 次式” とは仮説として同等である.したがって，より広沉な後者と同等な $H_{r}$ が実質的な意味 をもつ仮説である.

逆に昰が $H_{r}$ を満足し

$$
\gamma_{k}^{*}=(a+b) \eta+\left(k-\frac{a+b}{2}\right) \zeta
$$

と表わせるときには，同等な $\theta=\theta^{*}+\eta t_{2}+\zeta t_{3}$ を用いて，模型

$$
E\left[y_{\imath \jmath}\right]=\alpha_{\imath}+\beta_{3}
$$

を前提としてょい。

検定についての上の議論は $\Delta^{2} \alpha_{i}=0$ の検定, $\Delta^{2} \beta_{j}=0$ の検定についても成り立つ.

\section{4. 応用例}

次の 4 種類のデータに第 2,3 節の結果を適用する.

（1）男性肝硬変死亡率. 丹後, その他 [3,5] が解析したデータで, 年度は 1979-75，1974-70, ‥, 1959-55. 年踰層は 20-24，25-29，‥ 80-84 歳. 5 年間の肝硬变死亡数を中間年の人口の 5 倍で割った死亡率である. 朋 硬变增加の主原因は欲酒量增加によるとみなされている。

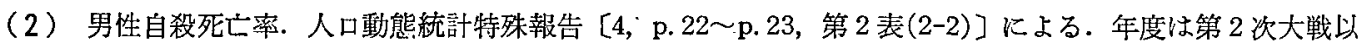

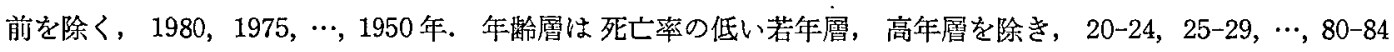
歳の死亡率である.1983年に中高年自殺が急增する現象が注目されているが，本稿の上らに年踰区分と年度間隔 が一致する，いわゆる標準コホート，のデータがないので，予備的解析として上記データに限った。

（3）“宗教を信ずるか”という質問にたいする肯定率.中村[6]，石井[2] が解析した，統計数理研究所国民性

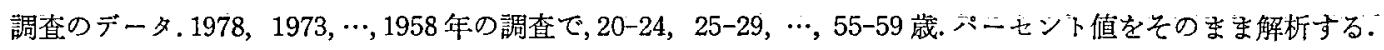

(4) 癌死亡率. Holford[9]の解析したアメリカ合衂国非白人前立腺癌死亡率. National Center for Health Statistics などのデータとよるもので, Ernster, 他 (1978 年 Science 誌) でも解析されている. 1969-65，1964 $-60, \cdots, 1939-35$ 年の 50-54, 55-59, …80-84 歳の死亡数を中問年人口で割った死亡率である.

4 種のデータの分析結果を第 3 表 A，Bに示す. 死亡数については，いかゆるポフンン回率に基く最尤推定と 最大尤度比検定, 和上び死亡率の対数の単純最小 2 乗推定, 分散分析と, 重みつき最小 2 乗推定, 分散分析を行 った．後者の場合, ポアソン分布を仮定し, その分散, すなわち, 平均値に単純最小 2 乗推定值を用いた. 最小 2 乘法の分散分析（第 3 表 A）を見ると，すべての場合で嗄羑が非常に小さくなる．そのため信仰率の世代以外 のすべての効果が高度に有意であり，時代の影響が弱いと予想される場合もその効果は有意となっている. 重み つき最小 2 乗法の分散分析は, 繰り返し数が異なる場合の 2 元分類の場合と同様, 行効果, 列効果に 2 つ定義 が考えられることになるので詳細は略し，第 3 表Aに世代効果のF 値だけ付記した．值がやや変るが高度に有意 であることに違いはない, 第 3 表 Bは肝硬変, 自殺, 癌の死亡数のポフンン回㷌模型で世代の最大尤度比検定 で,やはりいずれも高度に有意である.

差分を推定し，図示してもその解釉は簡単ではない，調査データでは諸要因の影響を受けるので，2階まで差 分をとると安定性がなく系統的な特徵がはっきりしない１階差分はより滑らかとなるが，差分の向きに注意し， 定数の不定性も考虑しなければならないので解釈しにくい.第 4 表は肝硬変の 2 階差分の最小 2 乗推定值と最尤 推定值である. 最尤法の誤差推定には情報行列の最尤推定量を用いる. 重みつき最小 2 乗法の結果は推定量も誤 
第 3 表 A. 分散分析表.（1），(2)，（4）は比率の対数

（1）男性肝硬変死亡率

\begin{tabular}{|c|c|c|c|c|}
\hline 要因 & 平方和 & 自由度 & 平均平方 & $F$ \\
\hline 年度 & 0.379 & 4 & 0.0947 & \\
\hline 年齢 & 198.958 & 12 & 16.5798 & \\
\hline 世代 & 2.768 & 15 & 0.1845 & $49.463^{* *}$ \\
\hline 誤差 & 0.123 & 33 & 0.00373 & \\
\hline 計 & 202.227 & 64 & & \\
\hline
\end{tabular}

重欢つき最小 2 乗推定の $F$ 值 $80.69 * *$

（2）男性自殺死亡率

\begin{tabular}{|c|c|c|c|c|}
\hline 要因 & 平方 和 & 自由度 & 平均平方 & $F$ \\
\hline 年度 & 3.541 & 6 & 0.590 & \\
\hline 年㱓 & 22.292 & 12 & 1.858 & \\
\hline 世代 & 1.545 & 17 & 0.0909 & 3. $772^{* *}$ \\
\hline 誤差 & 1.323 & 55 & 0.0241 & \\
\hline 計 & 28.701 & 90 & & \\
\hline
\end{tabular}

重みつき最小 2 乗推定の $F$ 值 $4.65^{* * *}$
(3) “宗教安信ずるか”

\begin{tabular}{|c|c|c|c|c|}
\hline 要因 & 平方和 & 自由度 & 平均平方 & $F$ \\
\hline 年度 & 0.06516 & 4 & 0.01629 & \\
\hline 年齢 & 0.58498 & 7 & 0.08357 & \\
\hline 世代 & 0.01419 & 10 & 0.001419 & 0.9404 \\
\hline 誤差 & 0.02717 & 18 & 0.001509 & \\
\hline 計 & 0.69150 & 39 & & \\
\hline
\end{tabular}

（4）癌死亡率

\begin{tabular}{|c|l|c|l|ll|}
\hline 要因 & 平 方 和 & 自由度 & 平均平方 & $F$ & 比 \\
\hline 年度 & 3.306 & 6 & 0.5510 & \\
年跉 & 44.361 & 6 & 7.3934 & \\
\hline 世代 & 1.356 & 11 & 0.1232 & $25.903^{* *}$ \\
\hline 誤差 & 0.119 & 25 & 0.00476 & \\
\hline 計 & 49.141 & 48 & & \\
\hline
\end{tabular}

重みつき最小 2 乗推定の $F$ 值 $14.03^{* *}$

** $1 \%$ 有意， *5\%有意を表わす

第 3 表 B．最大尤度比検定（ポアンン回㷌）

\begin{tabular}{|c|c|c|c|c|c|c|}
\hline & (1) & 最大対数尤度 & (2) & 最大対数尤度 $H_{r}$ & 自由度 & $2((1)-(2))$ \\
\hline 肝硬変 & & -264.14 & & -716.35 & 17 & $904.42^{* *}$ \\
\hline 自 殺 & & -978.32 & & -1659.68 & 19 & $1362.71^{* *}$ \\
\hline 癌 & & -252.59 & & -563.85 & 13 & $622.52^{* *}$ \\
\hline
\end{tabular}

年 度 効 果（新しい年度 $\rightarrow$ 古い年度）

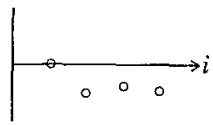

年 踰 効 果 (若年 $\rightarrow$ 老人)

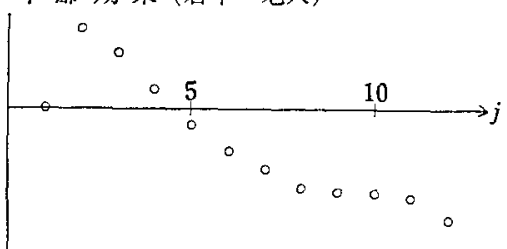

世代効果（若世代 $\rightarrow$ 老世代）

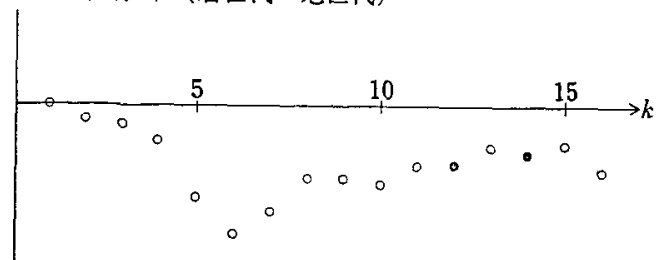

第 1 图. 男性肝硬変死亡率の 1 階差分 (ポフソン回緭)
年度効果

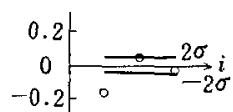

年 龄 効

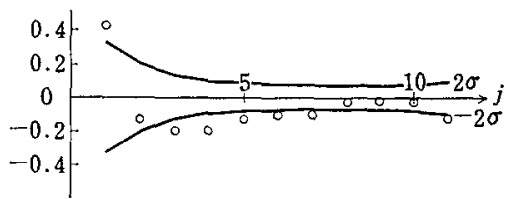

世代効果

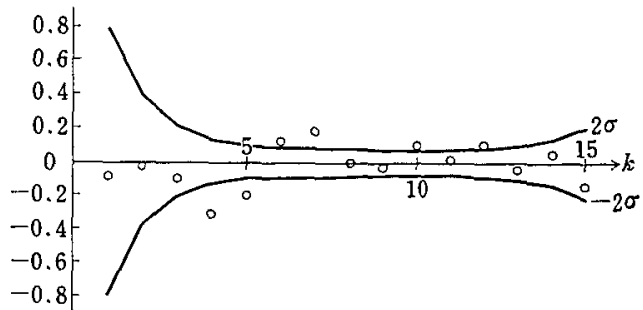

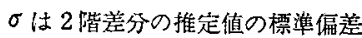

第 2 図. 男性肝硬变死亡率の 2 階差分 (ポアンン回帰) 
第 4 表. 男性肝硬変死亡率の 2 階差分の推定值とその標準偏差の推定値

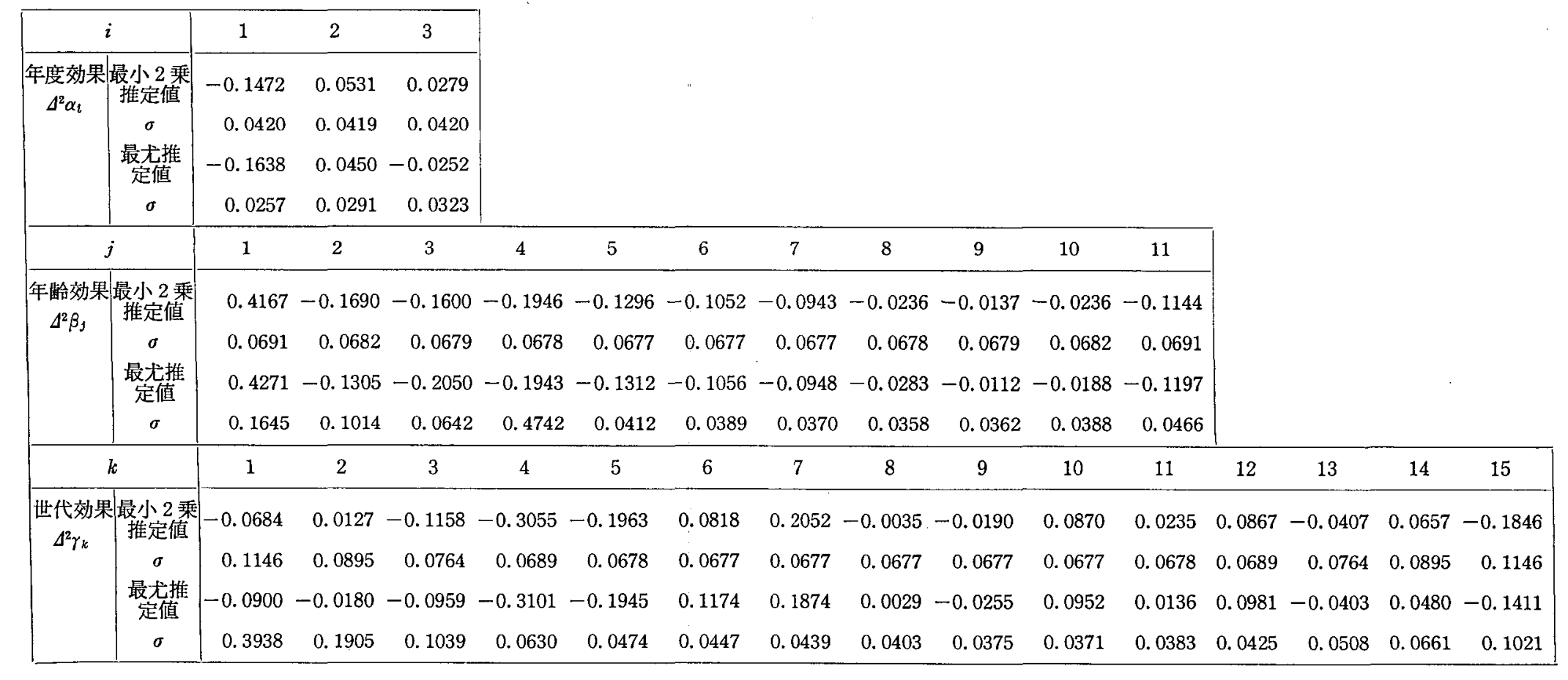


差推定も最尤法とほとんど同じで, 第 1 図，2図の最尤推定值の肝硬变の場合は此較的明確である. 年度効果で 新しい年度より最初減少ぎみなのが急增するため下に凸(正の 2 階差分)となり，その後ゆるやかになり続ける. 世代效果では 1925-35 年生まれの特殊性が言われて扣り，確かに2 階差分が負に突出している．それより15年前 に逆の突出もあり，変化の多さを示している．この点は第 6 節で再論する.

自殺，癌のデータについては，最尤推定値の 2 階差分，信仰率については単純最小 2 乘推定値の 2 階差分を第 3 図に示す。自殺死亡率の図る特徴的で，年踰効果では，若年層で高く中年に低くなってまた高くなる变化が大 きい，時代では戦後期と最近が凸で，高度成長期が凹である，世代では 1925-35 年生まれがやはり特殊である.

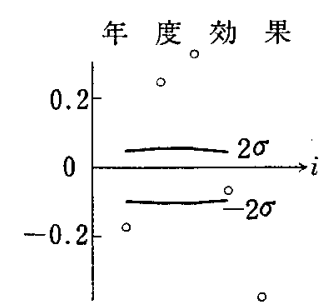

年 路 効 果

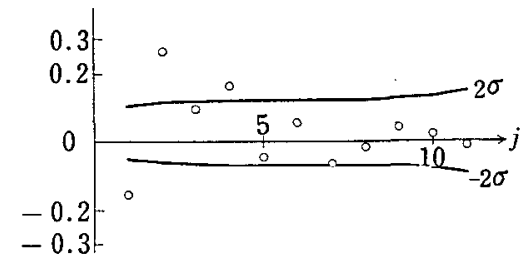

世 代 効 果

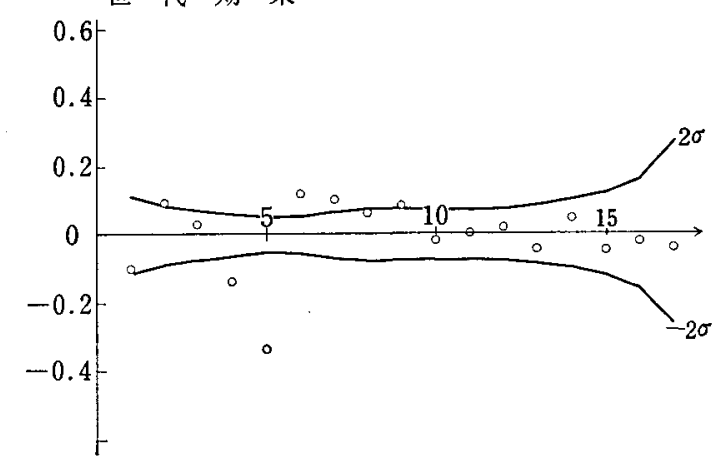

（a）男性自殺死亡率の 2 階差分（ポアソン回經）

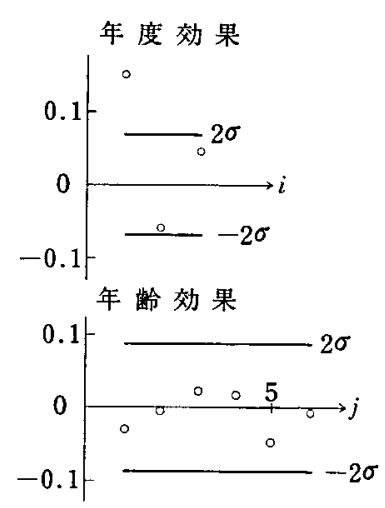

世代 効果

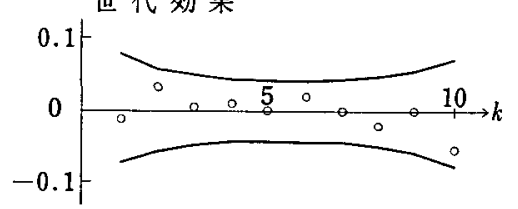

(b) “宗教を信ずるか”の 2 階差分 (最小 2 乗)

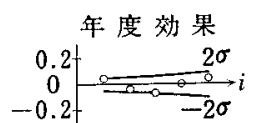

年 齢効 果

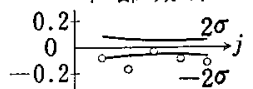

世代効果

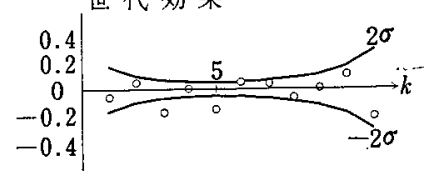

（c）癌死亡率の 2 階差分（ポアソン回㷌）

第 3 図

信仰率では時代の影響が意外とはっきりしているし，癌死亡率では年踰の影響が系統的である．他は高度に有 意なものもそれ㤬ど特徽的でない。

\section{5. 世代効果推定の批判}

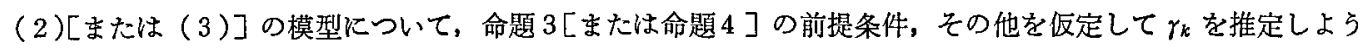
とする試みがある。しかしそのような努力は無益ではなからうか。 
第 2 節で注意したように，任意の母数 $\theta^{*}$ とたいして $\theta=\theta^{*}+\xi t_{1}+\eta t_{2}+\zeta t_{3}$ としても模型は変わらない，特に $\theta=\theta^{*}+\zeta t_{3}$ とすると,

$$
\sum_{i=1}^{a} \alpha_{i}=\sum_{i=1}^{a} \alpha_{i}^{*}, \sum_{j=1}^{b} \beta_{j}=\sum_{j=1}^{b} \beta_{j}^{*}, \quad \sum_{k=1}^{a+b-1} \gamma_{k}=\sum_{k=1}^{a+b-1} \gamma_{k}^{*}
$$

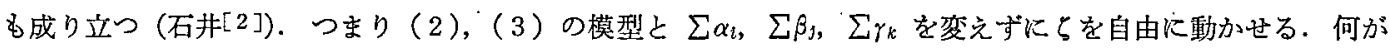
変わるか。直ぐ分かる関係は

$$
\Delta \alpha_{l}=\Delta \alpha_{i}^{*}+\zeta, \Delta \beta_{j}=\Delta \beta^{*}+\zeta, \Delta \gamma_{k}=\Delta \gamma_{k}^{*}-\zeta
$$

である．第 3 節で述べた，( $\left.\gamma_{k}\right)$ などの 2 階差分は線㔙推定可能たが， 1 階差分は定数たけ不定である，という事 実に対応している．命題（3）の条件式 $\left(\mathrm{b}^{\prime \prime}\right)$ を加えると（8）のらが0となることが必要となり任意性はな

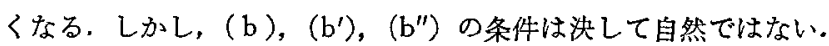

中村[6]，石井[2]は $\left(\alpha_{i}\right) ，\left(\beta_{j}\right) ，\left(\gamma_{k}\right)$ のそれぞれが系列として滑らかに変化する，という条件を課してい る、それは，たとえば（ $\left.\gamma_{k}\right)$ のばらつきを減少させることになり， $\gamma_{k}$ が単調に変化する解を排除する傾向とな る.どのような意味で“単純な”解を求めるか,がこの場合に恣意的である.

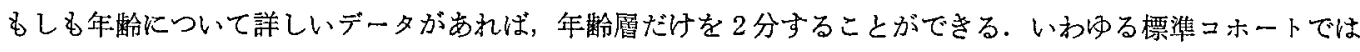

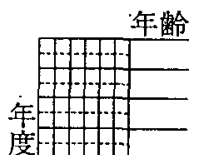

( a )

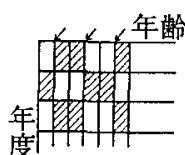

(b)
第 4 図

なくなり，2 世代が混合することになる（第 4 図 a ），そのときのデータを 元の枠組のまま見れば各欄で 2 の絽返しがあることになる（繰返しに系統 的な偏りが生じるのを無視する） 2 元分類で反復があっても推定可能な母数 は変わらず，謓美の自由度が增すだけである．ところで世代効果の区分間隔 を元のままに，しかし半期ずらして第 4 図bのように定義する。蔭はやは り1つ置きの世代を示す.するとデータの構造が変わり， $\Delta \alpha_{i}, \Delta \beta_{j}, \Delta \gamma_{k}$ が推定可能となる，という巧妙な方法 が丹後 $[3,5]$ によて考案された，その方法を桩張して，年㱓の詳細が分からないときにも，各欄のデータを 機械的に 2 分して新しい模型を適用することまで提案されている．後者は実質的に（2）の模型で $\Delta \gamma_{1}=0$ とお くことに近く，特に良い提案とは言えない，前者の場合も精度を検討すべきである.

Holford $[9]$ は，コホート模型の 3 效果 $\left(\alpha_{i}\right) ，\left(\beta_{j}\right) ，\left(\gamma_{k}\right)$ の各数列を, 添字の選点直交多項式に分解すること を行っている.それは何を意味するであるうか。

簡単のため，時代と年龄を連続量とし，記号も $u, v$ で表わす。観測量の期待値が $u, v$ の多項式

$$
p(u, v)=\sum_{\lambda} \sum_{\mu} c_{\lambda \mu} u^{\lambda} v^{\mu}
$$

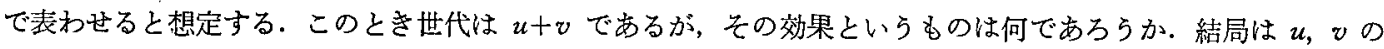
関数である. Holford の意図は不明瞭であるが，上の多項式を

$$
c_{00}+c_{10} u+c_{01} v+\left(c_{20}-\frac{c_{11}}{2}\right) u^{2}+\left(c_{02}-\frac{c_{11}}{2}\right) v^{2}+\frac{c_{11}}{2}(u+v)^{2}+\frac{c_{21}+c_{12}}{6}(u+v)^{3}+\frac{c_{22}}{6}(u+v)^{4}
$$

と表わし，u+vの 2 乗以上の項を世代効果としている，u+vでできるだけ多くを説明し，残りが $u ， v$ の成分

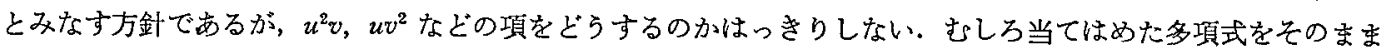
眺め, 時代についての少しの補外によって予湘を行うなどの手法が役立つであろう.

\section{2 相模型の可能性}

第 4 節（1）の肝硬変死亡率のデータに，年度・年跲の双方について 4 次の多項式（15項）扰よび年度につい て 4 次, 年龄について 5 次の多項式（30項）を当てはめた結果は第 5 表の通りである.これを補外して 5 年先を 
第 5 表. 多項式のあてはめ（肞硬変死亡率，第 3 表と比較せよ）

\begin{tabular}{|c|c|c|c|c|}
\hline & 平方 和 & 自由度 & 平均平方 & $F$ 比 \\
\hline$u, v の 4$ 次式 & 201.37 & 14 & 14.38 & $1722 . * *$ \\
\hline $\begin{array}{l}u, v 05 \text { 次以上 } u \text { は } 4 \\
\text { 次まで, vは } 5 \text { 次まで }\end{array}$ & 0.550 & 15 & .0367 & 4. $4^{* *}$ \\
\hline 譟 & 0.292 & 35 & .00835 & \\
\hline 計 & 202.22 & 64 & & \\
\hline
\end{tabular}

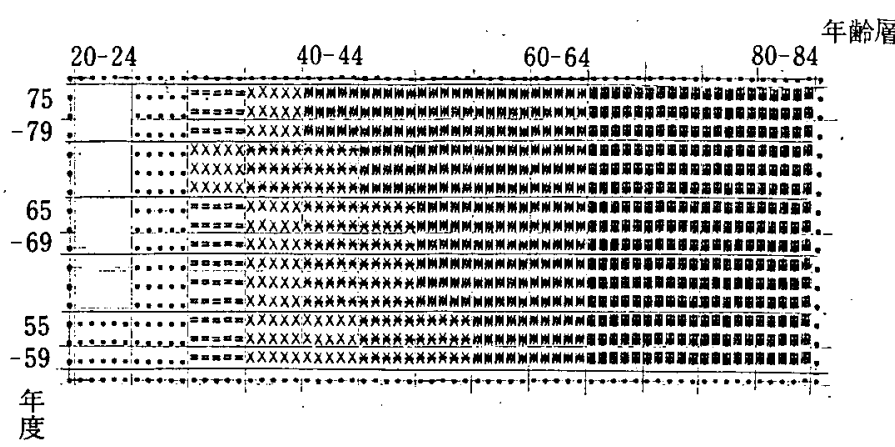

第 5 図. 肝硬变死亡率のデータの濃淡図

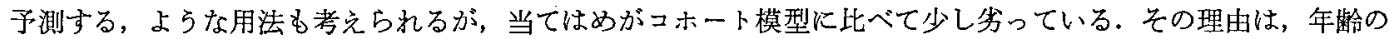
効果が 5 次式でる十分に近似できないためである。

原データ（死亡畜の対数）を濃淡図で表わした第 5 図括よび年龄を横軸とする世代ごとの死亡率グラフ（丹

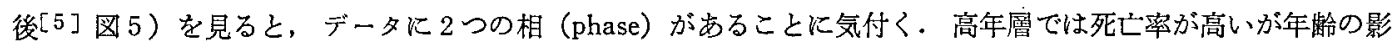
響が小さく，年度の効果が非常に小さい，若年層では年踰の影響が非常に大さく，年度の影響もある，中年層で は1つの相から他の相への移行が見られる。

このような不連続性を認めるとすれば，第 4 節で述べ，また丹後ら[3，5]も主張している，“1920-40年誕生の 世代は特異である”といら主張は疑わしくなる，むしるこの世代の頃から“潮の流れが变化した”とみなすこと ができる.“1920-1940 年生まれが不幸な最悪の世代なのではなく，中高年での死亡率が今後ますます増加する” という逆の予想も可能である.

2 相への分離といら非線形構造が世代効果といら錯視を与兄る可能性を検討するために次のよらな簡単な構造

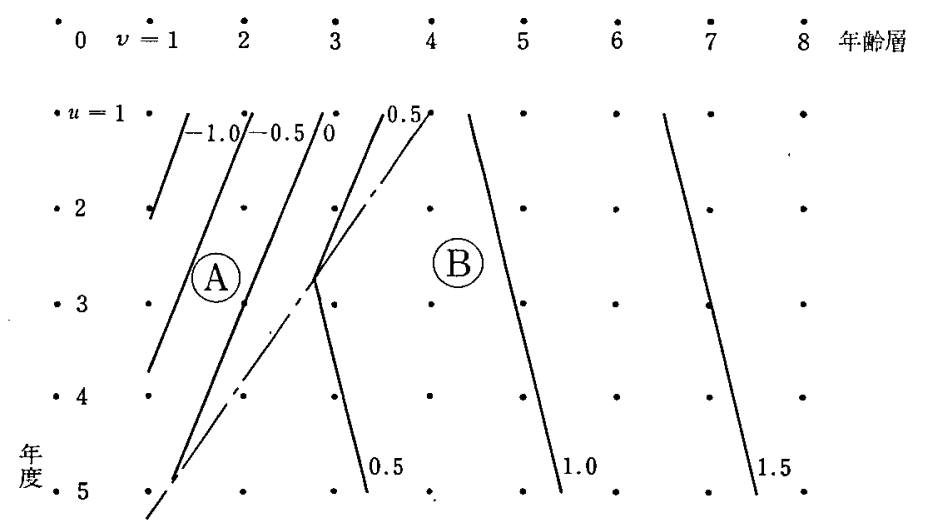

第 6 図. 2 相模型の領域区分と等高線.（9)，(10) 式参照. 第 5 図之対比せよ. 
を考えた，第 6 図のように，年度・年秢領域を A，Bに 2 分し

$$
\begin{array}{ll}
p=c_{0}+c_{1} u+c_{2} v, & (u, v) \in \mathrm{A} \\
p=c_{0}{ }^{\prime}+c_{1}{ }^{\prime} u+c_{2}{ }^{\prime} v, & (u, v) \in \mathrm{B}
\end{array}
$$

とする. A， Bの境界線は

$$
\left(c_{0}^{\prime}-c_{0}\right)+\left(c_{1}^{\prime}-c_{1}\right) u+\left(c_{2}^{\prime}-c_{2}\right) v=0
$$

である、第 6 図の等高線は

$$
\begin{aligned}
& c_{0}=-2.4, \quad c_{1}=0.3, \quad c_{2}=0.75 ; \\
& c_{0}^{\prime}=0, \quad c_{1}^{\prime}=-0.06, \quad c_{2}^{\prime}=0.24 ; \\
& u=1,2, \cdots, 5 ; v=1,2, \cdots, 8
\end{aligned}
$$

の場合の值で, 第 6 表は分散分析表と 2 階差分の単純最小 2 㐘推定值である. 濃淡图がある程度, 肝硬変死亡率

\begin{tabular}{|c|c|c|c|c|}
\hline & 平方 和 & 自由度 & 平均平方 & $F$ \\
\hline 年 齢 & 24.784 & 7 & 3.5406 & $147.1^{* *}$ \\
\hline 年 度 & 0.1135 & 4 & .02838 & 1.18 \\
\hline 世 代 & 1.5081 & 10 & .15081 & $6.26^{* *}$ \\
\hline 詥 差 & 0.04334 & 18 & .02407 & \\
\hline 計 & 26. 449 & 39 & & \\
\hline
\end{tabular}
の第 5 図に類似しており，世代の 2 階差分が乫出している点に注目されたい，ただし，肝硬变データは（9）式 ほど簡単な構造ではなさそうで，当てはめの算法が複雑となり，推定量の性質も十分に研究されていないので， もう 1 つ仮説として提案することしかできない，しかし，前述の多項式を当てはめた結果で，年度の方向に補 外すると，それほど無理ではない仮説である.

第 6 表. 2 相模型（9），(10）の分散分析

$\Delta^{2} \gamma_{\imath}$ の推定値とその標準偏差の推定値

\begin{tabular}{c|cccccccccc}
\hline$i$ & 1 & 2 & 3 & 4 & 5 & 6 & 7 & 8 & 9 & \multicolumn{1}{c}{10} \\
\hline$\Delta^{i} \hat{\gamma}_{i}$ & .017 & .011 & -.216 & -.215 & .010 & .014 & .011 & -.015 & -.007 & -.005 \\
$\sigma$ & .093 & .072 & .062 & .056 & .055 & .055 & .056 & .062 & .072 & .093 \\
\hline
\end{tabular}

\section{7. 世代効果の意味}

いったい世代効果なるるのが考兄られるのはどのような場合であるらか。“如何なる星の下に”生をれたか，と いらような運命論は問題外として，たとえば奻年期，少年期を1943-1950の食䊓久そ期に過ごした事実が，ある 成人病䍜患率・死因率に影響する可能性などであるらか. 肺結核の治療法として，一時期だけ普及した処置を受 けた人が老年期になって再発したり，他の病気を起こしやすい，といら場合などは比較的明白な例であるら。し たがって疫学で探索的データ解析を行うときには $\max \left|A^{2} \gamma\right|$ K着目することは役に立つであるう.

しかし人間一生の生活過程は複雑であり，世代共通に長年にわたり働く要因といらものは考党にくい，逆に特 定年度・年踰層の異常值を世代に㛿着させる危険がある. 最近の中高年層での自殺の急增を解积するのに，不況 や一部金融機関の不法活動，単身赴任など所帯経済事情を無視し，また若者の暴走による事故死といら準自殺行 為は無視して“跍い昭和一桁生まれと醒めた新しい世代”に帰着させる社会学者の発言が報道された（朝日新 聞[1])。コホート利用で安易なモデル化に走る危険がある。 


\section{参 考 文 献}

[1] 朝日新聞 (1984)：昭和ひとケタなぜ死に急ぐ，2 月22日（水）朝刊，13版 1 ページ。

[2] 石井健一 (1984)：コーホート・モデルの不定解の一つの表現とその応用, 応用統計学, 第13巻 1 号, $31-36$.

[ 3 ] 倉科周介, 丹後俊郎, 大林明 (1984): 肝硬变死亡の变遷に関する研究, 日本衛生学雑誌, 第 39 巻 5 号, 819-830.

４４］厚生省大臣官房統計情報部編（1984）：自殺死亡統計, 人口動熊統計特殊報告, p. 22-p. 23 厚生統計 協会.

[5] 丹後俊郎 (1984)：コホート分析に打污る年龄・時代・出生コホートの3 効果の推定について, 応用 統計学, 第13巻 1 号, 11-26.

[6] 中村隆 (1982)：ベイズ型コウホートモデル—標淮コウホート表への適用一一統計数理研究所裹報, 第29巻 2 号, 77-97.

[7] 広津千尋 (1983)：統計的データ解析, 日本規格協会.

[8] Glenn, N.D. (1977) : Cohort Analysis, Sage Publ., (藤田英典訳, 1984, 朝倉書店).

[ 9 ] Holford, T. R. (1983): The estimation of age, period and cohort effects for vital rates, Biometrics, Vol. 39, No. 2, 311-324.

[10] Longley, J.W. (1984): Least Squares Computations Using Orthogonalization Methods, Marcel Dekker.

[11] McCullagh, P. and Nelder, J. A. (1983) : Generalized Linear Models, Chapman and Hall.

[12] Namboodiri, N. Krishnan (1982) : Cohort analysis, Encyclopedia of Statistical Sciences, Vol. 2, $36-44$.

[13] Rao, C. R. (1973) : Linear Statistical Inference and Its Applications, 2nd ed., John Wiley (奥 野他訳, 1977, 東京図書).

訂正 男性肝硬変死亡率の解析では年間死し率を用いている．5 年間死亡率を用いると，ポフンン回㷌（第 2 図，第 4 表）では推定傗は変らず，その分散が $1 / 5$ の大きさになる。最大対数尤度（第 3 表B）も (1)-365.06，(2)-2365.33 となるが，挨定は 4000.53**となり，有意である. 重みつき最小 2 乗法で も同様. 分散分析の $F$ 比（第 3 表 $\mathrm{A}(1)$ ) は变わらない. 